\title{
1. Introduction: migration and global justice
}

\author{
Leanne Weber and Claudia Tazreiter
}

\section{MIGRATION AND GLOBAL JUSTICE IN CRISIS TIMES}

Human migration is a common feature of societies, yet in today's world with the securitization of nation-state borders, migration is often conveyed as a problem and migrants as risks to the societies they wish to enter. The securitized response of states to migration is contradictory given the signals that states give about the importance of global mobility to their economies, to growth, to cultural diversity - all benefiting domestic populations. And herein lies a key conundrum for this handbook in the tensions between international and national priorities, duties, laws, and also visions for human coexistence and harmony. Deliberations on migration fit squarely within these tensions.

Conceptions of global justice are articulated in a number of domains including the global resource allocation recognized as the root cause of global inequalities (Pogge 2001), as redistributive justice (Fraser 2007; Shachar 2009), articulated in new forms of membership (Bauböck 2009), as well as calls for symbolic recognition (Honneth 2004). From global justice perspectives, many writers have articulated for several decades the problems that result from the embedded nature of methodological nationalism in research, policymaking and social attitudes to human populations (Wimmer and Glick Schiller 2003; Glick Schiller et al. 2011; Faist 2010; Levitt et al. 2003). This methodology proceeds from the assumption that human populations are not only contained but metaphorically sealed within the 'container' of a nation-state, with the nation-state providing identity, resources and protections for members. While international law (particularly human rights), and so many other regulatory systems, operate with the human as the core concern, the nation-state system continues to prioritize members/citizens. Indeed, in the face of the rapid changes associated with globalization, which have decentred the state in some respects, the legal power to determine who is and is not admitted to territory and recognized as a citizen is one remaining arena of state control. Instead, commentators such as Satvinder Juss (2006) argue that migration should be recognized as both a moral and an economic imperative that is in line with what he calls 'global public interest'.

One key outcome for migrants from the contradictions inherent in restrictive models of border control and citizenship in otherwise deregulated globalized political and economic systems is exclusion from basic rights such as healthcare, education and social welfare. The serious consequences of differential treatment by nation-states of citizens and others have been brought into sharp relief by the onset of the COVID-19 pandemic. Since the official designation of the pandemic in March 2020 by the World Health Organization, restrictions on mobility, border closures and myriad other micro-changes to rules, regulations and policies that relate to access to healthcare, social welfare provisions, the right to work and other 'basic rights' are now evident in most states across the globe. This is despite consistent rhetoric from United Nations (UN) bodies urging a unified response to a problem of genuinely global scale. Accompanying these restrictions and measures is the political rhetoric by leaders of many nation-states, invoking a closed-border, citizens-only vision of who requires protection 


\section{Handbook of migration and global justice}

from the pandemic and forms of assistance to ameliorate the economic effects of pandemic interventions.

It is perhaps unsurprising that the mobility of persons, and the idea of people being able to 'carry bundles of rights' with them across nation-state borders, is one of the first lines of attack by nation-states when a perceived 'crisis' emerges (Collins 2019). While it has taken a public health crisis on a scale not experienced within living memory to lay bare the deficits in the rights and protections afforded to non-citizens, a 'crisis' mentality has been apparent for several decades in the selective securitization of borders mentioned earlier (Tazreiter 2019). The Handbook of Migration and Global Justice has been produced against the backdrop of these two crises: one a longstanding 'crisis' of human security and mobility engendered by structural change that nation-states have reinterpreted as a threat to national security and sovereignty; the other a real and newly emerging threat to human life that - along with other global challenges such as climate change - also demands new forms of governance and cooperation across borders. It would seem that the need for deep insights into the harms of current migration and citizenship policies, and new visions for a more globally just future in relation to the migration process and its aftermath, has never been more urgent.

The circumstances of COVID-19 and state responses to the pandemic highlight some key tensions and also potential new pathways towards global justice through the lens of migration. In 'crisis times' such as the present coronavirus pandemic, reversions to simple, yet often effective politics that casts outsiders and strangers as a problem for the state are evident in many national jurisdictions. Yet, at the same time, an existential crisis such as a pandemic focuses attention on what a society's core values are and to what extent vulnerable persons who happen to live in a particular territorial jurisdiction are protected or ignored (Carens 2013; Zaretsky 2019; Khazan 2020). It is an evident contradiction that, while migration patterns are now predominantly temporary, the dominant focus of policy and public discourse remains largely oriented towards stasis and permanent settlement. This results in a disconnect between policy, public discourse and lived reality. Temporary migrants, and indeed other categories of migrant, are sent mixed and often contradictory signals. Yet, temporary migrants also display a nimble approach of adaptation to fast-changing rules, conditions and opportunities. Herein lies a central conundrum for contemporary societies under the conditions of neoliberal globalization in welcoming the economic contributions migrants make to societies without granting them attendant rights and protections, as drawn out by several authors in this handbook (see Mezzadra and Neilson, Ness, Lee, Rosenberger and Schütze, Digidiki and Bhabha). Though temporary migration and the irregular status often closely associated with temporariness are fundamental aspects of contemporary global transformations that require just this nimble adaptability, the burdens arising from legal, economic and socio-cultural exclusions that result from contemporary bordering practices are largely borne by migrants.

\section{OVERVIEW OF THE COLLECTION}

This handbook features leading international scholars and commentators from a range of disciplinary and geopolitical perspectives, who have agreed to take up the task of developing new visions for a more globally just future in relation to migration. The authors' professional backgrounds span legal theory and practice, border criminology, sociology, gender studies, anthropology, public health, politics, social work, journalism, refugee studies, human rights, 
political philosophy, public policy and advocacy, cultural studies, literature and the visual arts. This breadth is testament to the ubiquity of concern about migration and global (in)justice across many spheres of human activity and debate. While the majority of contributors are academics, the collection also includes the voices of those who have personal experience of the injustices inherent in contemporary migration regimes (see especially chapters by Fleay and co-authors, Tofighian and Gržinić), alongside academics and practitioners who have gone on to become advocates for change (such as Bolton and Jarvis, Fleay et al.).

The collection addresses the relationship between migration and global justice at a range of scales, revealing the dynamics of global processes as they manifest at local and regional levels, and exploring the role of both international mechanisms and local forms of civic participation and governance. Our authors are drawn from five continents, and their contributions range from more abstract and theorized analyses (Mezzadra and Neilson, Simeone and Piper, Owen, Wonders and Jones), to empirical case studies situated in Australia/Manus Island (Sharples and Briskman, Fleay et al., Tofighian), Hong Kong/China (Lee), India (Mehta), Malaysia (Ness), Chile (Ramos-Rodríguez et al.) and small-town USA (Kivisto). In some chapters, whole regions such as the Mediterranean and Caribbean basins (Digidiki and Bhabha), Central America (Varela Huerta), Austria and Europe (Rosenberger and Schütze, Gržinić), and Europe/Australia (Bolton and Jarvis) are put under the microscope.

The handbook is organized under four thematic headings: Migrant Workers as Global Labour; Failures in Refugee Protection; Non-citizens, Rights and Belonging; and Achieving Global Justice in and through Migration. Chapters in the first three parts concentrate primarily on identifying the existing practices - including both structural conditions and state policies - that reflect and contribute to global injustice in life chances on the basis of citizenship and place of birth. In the final part, authors articulate possibilities for increased equity and fairness in the capacity of human beings to cross borders in search of employment, physical safety or an improved quality of life, and to realize these aspirations in their new place of residence.

Migrant Workers as Global Labour includes critical pieces on the reconfigurations of global labour and thereby international immigration in response to renationalization, the hardening of borders, and the exploitation of undocumented and temporary migrant workers. Areas of focus include international legal protections for migrant workers, discussed from the perspectives of law, political economy and international relations, gender studies, postcolonial studies and transnational criminology.

The first chapter in this part, by Mezzadra and Neilson, shows how labour and geopolitics are intricately entwined, with notable consequences for migration and justice. Mezzadra and Neilson argue that the introduction of just-in-time and to-the-point migration schemes, along with renationalization evident in many parts of the world, significantly reconfigure the geopolitics of labour - with consequences for how justice is experienced and not merely theorized. The authors remind the reader of the multiplicity of borders beyond state borders in the form of metaphysical, relational and social borders. At the heart of the chapter, state responses to migrants due to the coronavirus are assessed in relation to the practice of global justice.

Immanuel Ness focuses on the experiences of temporary labour migration in Southeast Asia, with an analysis of the role of non-governmental organizations, international organizations and, to a lesser extent, national union representation to ameliorate worker exploitation and advocate for their rights as undocumented non-citizens. Ness develops a particular critique of temporary migrant labour in Malaysia. The chapter gives a background to the growth of temporary labour migration schemes since the 1980 s in the era of neoliberal globalization, 
with a critique of the deficient global labour standards in view of these developments. With Southeast Asia as a major global labour migration corridor, Malaysia has positioned itself as a key regional player for foreign direct investment, leading to the growth of migrant labour for electronics and new technology industries. Ness demonstrates the manner in which the abuse and exploitation of temporary migrant workers is facilitated (and hidden) through these systems of global capital networks and alliances. Gender aspects of temporary migrant labour are a key issue, with women making up a large proportion of migrant workers in Malaysia.

The next chapter also discusses migrant labour in the Southeast Asian region. Positioning her analysis of domestic migrant labour in Hong Kong in the context of the COVID-19 pandemic, Maggy Lee demonstrates the lived injustice experienced by women migrant domestic workers. The work of feminist sociologist Nancy Fraser motivates Lee in drawing our attention to economic as well as symbolic injustice in the lives of these women. Lee demonstrates the ways in which states have reinforced punitive border policies through the COVID-19 context. In terms of global justice, Lee's chapter documents the feminization of poverty, inequality and disenfranchisement experienced by female migrant workers.

Ramos-Rodríguez et al. provide a detailed, contextualized analysis of migration management in Chile, described as neoliberal technologized bordering. Similar to many other states, such as Australia, Chile has withdrawn from the Global Compact on Refugees, which would offer an opportunity to recalibrate policies towards a global justice agenda. The authors describe the circumstances of migrant labour and undocumented migrants, and the new restrictive policies of securitization, criminalization and deportation.

Chapters in the Failures in Refugee Protection part of the volume assess the circumstances of refugees, displaced persons, child migrants and undocumented migrants in the changing global climate of securitization, renationalization and populist politics in many parts of the world. The chapters in this part are drawn from researchers, activists and legal practitioners and highlight the voices and accounts of people with lived experience as refugees, displaced and undocumented persons.

Rosenberger and Schütze's chapter engages squarely with the conundrums and tensions that arise when considering global justice in a migration context. The chapter focuses on basic social rights in the European Union beyond national citizenship. Rosenberger and Schütze describe the politics of the migration-welfare nexus, whereby welfare benefits are customarily reduced or removed for some categories of 'irregular' migrants and rejected asylum seekers as a form of deterrence and to facilitate renationalization. EU case studies of sanctuary cities and the idea of urban citizenship rights for all, whether documented or undocumented, are explored.

The next chapter, by Digidiki and Bhabha, shows how the externalization of borders and responsibility for vulnerable migrants by wealthy states exacerbates the suffering of migrant children and their families. The focus is on the Mediterranean and Caribbean basins as evidence of these policies and their impacts on the lives of migrant children. With the externalization of humanitarian responsibilities, Digidiki and Bhabha argue that the principles of protection are not only undermined but so fragmented as to have disappeared. Importantly, the authors explain the disingenuous nature of the politics of 'saving lives' as a humanitarian endeavour, deployed as a political and policy strategy by Western states, without any accompanying strategy for ensuring the protection of migrants denied entry to Western states in order to engage protection obligations. 
The case study of Australia's externalization of its borders of protection by Tofighian is a powerful chapter in its focus on the lives and voices of refugees subject to detention in the 'offshore' locations of Manus Island, Papua New Guinea and the island state of Nauru. Australia's 'border industrial complex' is described and teased apart in micro detail through analysis of the deaths of those detained through medical neglect, suicide, and murder by guards. Writing in the style of a philosopher/advocate, Tofighian draws on the social media interventions of Behrouz Boochani, detained on Manus Island for over seven years. The chapter reveals the close scholarly and creative collaboration that developed between Boochani and Tofighian over many years, beginning with Tofighian's work translating Boochani's journalism and later creative works. Through the detailed appraisal of refugees' lives and suffering at the hands of the Australian Government, Tofighian develops an argument for the abolition of immigration detention.

Beginning with the circumstances refugees in Europe face in the context of the coronavirus, the chapter by philosopher and video artist Marina Gržinić analyses Europe as a 'castrated space', where Occidental and colonial reason remain embedded in mentalities, in the very DNA of decision-making. For Gržinić, the historical validation of the extraction of resources and enslavement of peoples from former colonies casts long shadows in the present. Indeed, she notes that traces between the past and the present are all too evident in the treatment of refugees in contemporary Europe through incarceration, marginalization and indifference at their death.

In the final chapter in this part, Varela Huerta describes the plight of Central American women fleeing three forms of structural violence: violence perpetrated by the state, economic violence and patriarchal violence. Drawing on the voices of women migrants and the accounts of non-governmental actors, Varela Huerta weaves a compelling analysis of the decision-making of Central American women and girls fleeing homes and families in search of safety and dignity.

The part entitled Non-citizens, Rights and Belonging focuses on post-migration experiences and practices. The authors use detailed case material to reveal the struggles of various categories of non-citizens to access entitlements and human rights protections and to develop a sense of acceptance and belonging, even after long periods of residence.

In the opening chapter, Rimple Mehta takes us to India and the challenges faced by non-citizens of Bangladeshi origin, many of them longstanding residents, who are threatened by the exclusionary implications of a National Register of Citizens that discriminates openly against Muslim minorities. Mehta uses her fieldwork with Bangladeshi women imprisoned for breaching poorly understood migration and citizenship laws to illustrate how individuals occupying the margins of religious, class, race, caste and gender hierarchies struggle to claim the 'right to have rights'.

Peter Kivisto provides a detailed case study of the highly politicized workplace raids that took place in the small town of Postville, Iowa; examines their socio-political and legal context, including shifting local attitudes towards successive arrivals of both legally recognized and undocumented workers; and considers their legacy, including increased awareness of the unresolved interconnectedness between local conditions and global processes. While he notes that some civic leaders made genuine efforts to promote inclusion, Kivisto concludes that ongoing structural inequalities on a global scale ensured that the dream of making Postville 'hometown to the world' remains aspirational. 
Sharples and Briskman draw upon the pandemic in a series of case studies that illustrate the implications of the absence of rights for certain groups of non-citizens in a time of crisis. They conclude that the Australian Government has reneged on its national and international obligations towards international students, seasonal migrant workers, and asylum seekers living in the community, heightening their already precarious position by withdrawing support at a time when it is most needed. While the global health crisis has brought these failures into sharp relief, the authors note that denial of rights along racialized lines is consistent with Australia's historical framing of its national imaginary in terms of whiteness.

This section concludes with a highly theorized chapter by Lisa M. Simeone and Nicola Piper focused on global institutions and systems. These authors consider the justice implications for migrants of a global shift towards governance through considerations of security and risk. Highlighting the tensions between human security, national security and financial security of global markets, they argue that the securitization agenda, and the structural contradictions that give rise to it, have created an 'impasse of migrant rights'. They note that the emerging regime of global migration governance, while employing the language of human rights, is nevertheless limited by the pragmatic concerns of national security and the stabilization of the global capitalist system.

The final part, Achieving Global Justice in and through Migration, contains four chapters that confront this challenge in contrasting ways, at both a theoretical and a practical level. In the opening chapter, philosopher David Owen seeks to reframe debates about migration and global justice by exploring how distinct views about the nature of global justice - and the role played by migration in achieving it - point to different approaches to migration governance. While not advocating for any one approach, his detailed analysis draws out the implications of three alternative stances: liberal statism, liberal cosmopolitanism and republican internationalism.

In the chapter that follows, former legal professionals Syd Bolton and Catriona Jarvis tell a moving story about the origins and actions of their non-governmental organization Last Rights, which advocates for 'justice in death' for migrants lost in transit. They attribute responsibility at the international, national and local level for ensuring that bereaved families of deceased or missing migrants receive the care and support they need, and call for an end to impunity for those responsible for border-related harm, including harms arising from border control policies.

Caroline Fleay, Mary Anne Kenny, Atefeh Andaveh, Salem Askari, Rohullah Hassani, Kate Leaney and Teresa Lee combine their experiences and insights to provide another activist perspective in a chapter that recounts the formation and activities of the Western Australian Refugee and People Seeking Asylum Network. This highly reflexive discussion models the collectivist approach adopted by the network, which seeks to disrupt power differentials between Australian citizens and those with lived experience of asylum seeking, while making visible to authorities the lives of individuals made vulnerable by harsh policies directed towards them.

In the final chapter of the handbook, Nancy A. Wonders and Lynn C. Jones note that global capitalism is now the main source of power in a world of increasingly multi-scalar power relations. Since governments have few incentives to disrupt the privileged access to cross-border mobility enjoyed by global elites, the authors turn to the literature on social movements to consider whether justice in mobility entitlements can be achieved from below, noting that hostile 
policies towards unwanted border crossing have the capacity to foster collective identities and to provide a basis for solidarity and political action.

\section{PATHWAYS TO GLOBAL JUSTICE IN AND THROUGH MIGRATION}

\section{Authors' Conceptions of Global Justice}

In seeking to critique and remedy present contradictions and injustices in migration, our contributors have adopted a variety of conceptions of global justice. Some explicitly articulate a position on this core theme by referencing the global justice literature, while in other cases a personal vision of what might constitute global justice is implied from the discussion. In more theorized contributions, references to global justice are relatively abstract, while authors of more empirically informed chapters tend to adopt an approach to global justice that is specifically linked to their case material.

Mezzadra and Neilson's perspective of global justice in relation to migration is grounded in the conceptualization of a geopolitics of labour. Here, geopolitics is understood through migrants as a 'subjective dimension of border crossing'. Indeed, this highly original contribution stresses that migration ought to be recognized as 'a barometer of geopolitics and global economic conditions [and] also register and align itself with the subjective experience and agency of border crossers' (p. 23). Importantly, Mezzadra and Neilson assert in their conclusion that border struggles also attest an ungovernable component at the heart of migrant subjectivity - the indivisibility of the human and ultimately that which the state cannot account for or predict.

Other authors also embed their conceptions of global justice and injustice in both the subjective experience of those who have crossed borders and the wider global structures that shape their experience. Peter Kivisto's detailed case study of the changing fortunes of migrant labourers originating from both within and beyond the borders of the United States vividly illustrates the dynamic influence of geopolitical factors, in combination with local conditions and sentiments. His conception of global justice is one in which equal concern and protection are provided for workers regardless of origin or legal status. This stands in contrast to the 'exclusionary nativism' on display in the large-scale workplace raids that are the subject of his analysis.

David Owen's more philosophical approach engages on a more theoretical level with the wider structural conditions determining the justice implications of various approaches to global migration governance. He sets out a fundamental distinction between global justice in migration and through migration. For him, the relationship between migration and global justice is not simply a question about 'justice in migration' - that is, the rights of individuals to engage in transnational migration or the rights of states to control such movement; it is also a matter of the value of migration as an instrument for realizing other ends of global justice. Adopting this broad perspective, for example, identifies the outward migration of skilled professionals as a matter not merely of individual fairness, but also of global justice from the perspective of less-developed states.

For Omid Tofighian, global justice is evident in the micro-politics of resistance that he describes, arguing that epistemic as well as practical shifts are required in order for a more 
just order to emerge. Through the empirical cases he explores, he identifies not only the Australian state, but also average citizens and institutions such as universities as playing a role in acknowledging the systems of knowledge-making that exclude other ways of being and thereby other persons.

For Maggy Lee, the empirical detail of care work and feminized labour in Hong Kong demonstrates the enormous gulf in realizing global justice while at the same time providing hope in the form of active resistance and solidarity. The recent pro-democracy movement in Hong Kong shows 'shared struggles between the emerging pro-democracy movement and the migrant movement' (p. 58).

Fleay and her co-authors adopt an understanding of global justice that reflects an active commitment to those beyond one's own national community, based on the view that 'national borders are arbitrary and therefore morally irrelevant' (p. 279). They also see globalization as shaping these new commitments as it becomes apparent that 'our lives have impacts on others both within and beyond the borders of the country in which we reside' (p. 279).

Also approaching the idea of global justice from an activist perspective, Nancy Wonders and Lynn Jones envisage global justice arising from the empowerment of populations, notably those populations that are negatively impacted by restrictive border controls. They note: 'Rather than conceiving of the pursuit of global justice in terms of an outcome, we conceptualize it as a process through which ordinary people are able to gain and exercise power' (p. 307).

\section{Pathways to Global Justice}

Reflecting their different approaches to conceptualizing global justice, authors in this volume have also set out a variety of pathways towards the achievement of global justice. Handbook authors present visions for a more just world in relation to migration that advocate the need for global structural change; for shifts away from threat perceptions associated with outsiders; for universal human rights guarantees and redistributive justice; and call for global solidarity and cross-border activism.

David Owen focuses on how several prominent strands of normative theory would approach the challenge of achieving justice in access to migration, while also addressing the broader challenge of global injustice and inequality. He finds that liberal cosmopolitanism, to take one example, adopts a conception of global justice that 'encompasses equal rights and equal opportunities' (p. 246). This leads to a position on justice in migration of relatively open, but not totally unregulated, borders, yet also 'requires building a global basic structure to secure global background justice' (p. 248).

Several authors address the need for change in the broader structures of colonialism and global capitalism that fuel global injustice. For Simeone and Piper, the pathway to global justice may rest in acknowledging and resolving the structural contradiction whereby the forces of financial securitization inherent in global capitalism actually threaten the security of both the migrant and the state.

Alongside changes in economic structures, some authors identify transformations in threat perception towards greater moral inclusion as crucial steps along the pathway to global justice in migration. For Mehta, the pathway to justice for marginalized non-citizens in postcolonial India requires adopting '[t]he lens of intersectionality' and a capacity to rethink difference as something other than a basis of historical subordination. To achieve this, she argues, '[c]are needs to be an essential building block of the edifice of justice', replacing a set of relations 
based on 'threat perceptions' (p. 181). Sharples and Briskman also mount a moral argument for greater inclusion in the polity of non-citizens who 'serve the needs of the dominant society' (p. 216), which is predicated on moving beyond the historical patterns of racism and re-colonization that have defined the Australian nation-state.

Sieglinde Rosenberger and Theresa Schütze, along with several other authors, see global justice manifest in the form of basic social rights for migrants. Proceeding from the ethics at the heart of international human rights, the authors eschew the attempts by individual members of the European Union to deny the shared protections they are obliged to extend to refugees and asylum seekers. In denying the fundamental human rights of persons in their territory (even if failed asylum seekers), welfare states undermine global justice and arguably thereby also undermine the foundations of the ideal of liberal states.

Vasileia Digidiki and Jacqueline Bhabha stress the two Global Compacts, on refugees and migrants, that were signed by the majority of UN member states in December 2018. The Compacts remind states of their obligation to children. The authors argue that the humanitarian ideals at the heart of the Compacts ought to be a pathway towards global justice.

Sharples and Briskman also associate access to the full range of human rights with the realization of global justice, equating universal rights protection with social inclusion on a global scale. In fact, like Mehta, they evoke Hannah Arendt's 'right to have rights' as a fundamental indicator of inclusion within a human community. For Rimple Mehta, equality and fairness in access to the benefits of citizenship are a key component of justice for Bangladeshi residents in India. Relying also on the subjectivities of her research participants, she identifies a vision of justice vis-à-vis various groups of migrants as follows: 'I advocate for a formulation of a system of justice that will impact two groups of people: first, the Bangladeshi woman prisoner who has no claim to rights and no way to establish legitimacy in India or Bangladesh; and second, the marginalized Indian citizen who is a citizen with or without documents, though there are other ways of establishing their "legitimacy"' (p. 174).

Simeone and Piper's chapter also projects a vision of global justice cast in terms of equality of rights and access to the broader conception of human security. These authors note that the ongoing tension between state sovereignty and universal rights consistently undermines efforts to address 'the "migrant rights deficit" of the global justice regime' (p. 222), with borders playing a crucial role to 'preserve the inequalities that allow capitalism to function' (p. 226).

Also adopting a rights-based approach to global justice, Syd Bolton and Catriona Jarvis invite us to consider the rights of those who die or go missing while attempting to cross borders, and of their families, reminding us that justice in death will remain an essential consideration for as long as migrants continue to face heightened risks arising from border securitization.

The adoption of an effective and truly universal human rights system that collapses distinctions between citizen and non-citizen is a vision shared by many contributors. For Sharples and Briskman, the Arendtian concept of the right to have rights, regardless of legal status, is the starting point for the realization of global justice that transcends borders and the exclusive interests of receiving states.

However, the pathway towards the dissolution of distinctions between citizens and non-citizens in terms of protections and entitlements will not be straightforward. Peter Kivisto's chapter documents the aspirational efforts of sections of the local population who sought to style the small town of Postville, Iowa, as 'hometown of the world', largely by stressing the universality of human rights. In contrast to these 'bottom-up' efforts, the workplace 
raids reported by Kivisto reflected 'the tension between a commitment to universal norms and the liberal nation-state's boundary-drawing between citizens and aliens' (p. 198). One reason for the failure to bring about lasting change was the inability of the local actors to combat the structural issues faced by undocumented migrant workers, including national policies and the broader sources of global injustice wrought by US imperialist engagement in many countries from which successive waves of workers originated.

Top-down efforts to strengthen rights protection for migrants may be equally fraught. According to Simeone and Piper, instruments such as the Global Compact for Migration actually serve on the one hand to prolong the 'impasse of migrant rights' by 'safeguarding the liquidity of labour markets' (p. 223). On the other hand, they claim that the broader vision of global justice envisioned in the Sustainable Development Goals, and other steps towards a broader conception of security pursued by UN institutions, are increasingly revealing the irrationality of retaining inequitable treatment of migrant workers that drives further risk and volatility under conditions of global crisis.

Bolton and Jarvis envisage justice for deceased and missing migrants as arising from multiple sources. At a national level, justice might include criminal prosecution of those with proximate responsibility for deaths, civil remedies including reparation for the losses suffered by grieving relatives, and processes of truth telling and support for the bereaved. These authors see the ingredients for a truly global form of justice as being already available within international human rights instruments that governments have so far failed to enforce. Instead, they have chosen to recruit civil society at the international, national and local levels to support their Mytilini Agreement, with a view to promulgating and generating adherence to 'soft jurisprudence norms' and generate cooperation across borders.

Global justice can also be pursued politically through global solidarity and activism, with or without explicit recourse to human rights norms. In the chapter co-written by an activist group that supports asylum seekers in Western Australia (Fleay et al.), global justice is seen as arising and being shaped by civil society, particularly through the political involvement of marginalized and oppressed groups. While acknowledging the global forces that shape unjust border control policies in specific places - in their case, the temporary protection regime for recognized refugees in Australia - this group of citizens working with affected non-citizens targets their activism by advocating for reforms at both the state and federal level.

While other authors also emphasize the role of non-state actors, such as civil society and non-citizens impacted by migration policies, the explicit decentring of the state by Wonders and Jones opens up space for those affected by restrictive migration policies to seize justice in and through migration, for themselves. These authors note that governments have few incentives to extend mobility entitlements beyond currently privileged groups, but that unauthorized border crossers assert their power and humanity through their acts of border crossing and navigation of 'unauthorized' status, often assisted in this challenging of power relations by citizen allies.

\section{COVID-19 and Other Global Challenges as Possible Turning Points}

As the chapters in this handbook were drafted at the height of the COVID-19 crisis, it is not surprising that some authors choose to address in their chapters some of the pandemic's consequences for migration and global justice. Peter Kivisto, for example, notes the contradiction inherent in the efforts made by then president Donald Trump to physically exclude undocu- 
mented migrants, while at the same time expecting them to continue working in meatworks during the crisis, at great personal risk - comparing this episode to other historical examples of exploitative inclusion.

In building their discussion of the geopolitics of labour as redefining the spaces and scales of justice for migration and border struggles, Mezzadra and Neilson point to the renationalization of borders due to COVID-19. The consequences of this new hardening of borders are still unfolding. As Lee points out, the pandemic has exposed and exacerbated existing inequalities. For example, global labour migrants are experiencing extreme poverty and rising unemployment as a consequence of the heightened economic stress caused by the pandemic. For Simeone and Piper, the COVID-19 pandemic is one manifestation of a broader crisis of human security. State responses that have typically increased the precarity of migrants through border closures and denial of relief have widened the 'migrant rights deficit' rather than adopting a global perspective on human security that is demanded in response to crises that are unfolding on a number of fronts.

This widening of the migrant rights deficit during a time of crisis is readily apparent in the chapter by Fleay et al. They observe that people living on temporary visas - many of whom are desperately worried about the plight of relatives living abroad in areas with high infection rates - have been excluded from the financial support packages provided by the Australian Government for citizens and permanent residents. Other authors note that COVID-19 restrictions have brought into sharp relief the injustices faced by migrants in transit and in countries of destination that often remain invisible (see, for example, Wonders and Jones).

Through the diverse and original perspectives of the authors gathered in this handbook, the everyday lives of adult and child migrants, migrant workers, refugees and displaced persons are made visible. The restrictive and often punitive actions of nation-states targeting many different categories of migrants as non-citizens are the cause of great concern among proponents of global justice in recognizing the fundamental rights and dignity of persons over and above national membership. In the globalized neoliberal system of late capital (and late modernity), states gesture towards upholding the human rights of all peoples yet implement policies and legislation that create precarity including through a lack of access to the rights framework people require for sustainable life. As our authors demonstrate, resolving the contradictions inherent in our current approaches to migration and global governance in ways that support global justice will require multi-scalar change to address global socio-economic inequality, generate acceptance of recent and even longstanding migrant groups by populations, and break down aspects of the citizen/non-citizen divide that limit the realization of a truly global vision of human rights that embraces all humanity.

\section{REFERENCES}

Bauböck, Rainer (2009), 'Global justice, freedom of movement and democratic citizenship', European Journal of Sociology/Archives Européennes de Sociologie, 50(1), 1-31.

Carens, J. (2013), The Ethics of Immigration, Oxford: Oxford University Press.

Collins, Jock (2019), 'Migration to Australia in times of crisis', in Cecilia Menjivar, Marie Ruiz and Immanuel Ness (eds), The Handbook of Migration Crises, Oxford: Oxford University Press, pp. 817-831.

Faist, T. (2010), 'Transnationalization in international migration: implications for the study of citizenship and culture', Ethnic and Racial Studies, 36(10), 2271-2274. 


\section{Handbook of migration and global justice}

Fraser, N. (2007), 'Reframing justice in a globalizing world', in T. Lovell (ed.), (Mis)recognition, Social Inequality and Social Justice: Nancy Fraser and Pierre Bourdieu, London: Routledge, pp. 17-35.

Glick Schiller, Nina, Darieva Tsypylma and Sandra Gruner-Domic (2011), 'Defining cosmopolitan sociability in a transnational age: an introduction', Ethnic and Racial Studies, 34(3), 399-418.

Honneth, A. (2004), 'Recognition and justice: outline of a plural theory of justice', Acta Sociologica, 47(4), 351-364. doi:10.1177/0001699304048668

Juss, S. (2006), International Migration and Justice, Aldershot: Ashgate.

Khazan, Olga (2020), 'How the coronavirus could create a new working poor', The Atlantic, 15 April.

Levitt, Peggy, Josh DeWind and Steven Vertovec (eds) (2003), 'Transnational migration: international perspectives', special issue of International Migration Review, 37(3).

Pogge, Thomas (2001), 'Priorities of global justice', Metaphilosophy, 32(1/2), 6-24.

Shachar, A. (2009), The Birthright Lottery: Citizenship and Global Inequality, Cambridge, Mass.: Harvard University Press.

Tazreiter, C. (2019), 'Crisis politics of asylum seekers and migrant arrivals in Australia', in Cecilia Menjivar, Marie Ruiz and Immanuel Ness (eds), The Handbook of Migration Crises, Oxford: Oxford University Press, pp. 619-634.

Wimmer, A. and N. Glick Schiller (2003), 'Methodological nationalism, the social sciences, and the study of migration: an essay in historical epistemology', International Migration Review, 37(3), 576-610.

Zaretsky, Robert (2019), 'The cure for the plague is decency: for times of extremity, Albert Camus prescribed modest virtues', Foreign Affairs, 1 November. 